University of Nebraska - Lincoln

DigitalCommons@University of Nebraska - Lincoln

$10-2-2018$

\title{
Checklist of Bloodfeeding Mites (Acari: Spinturnicidae) from the Wings of Bats (Mammalia: Chiroptera) in the Manú Biosphere Reserve, Peru
}

Donald D. Gettinger

Manter Laboratory of Parasitology, University of Nebraska-Lincoln, donaldgettinger@gmail.com

Follow this and additional works at: https://digitalcommons.unl.edu/manter

Part of the Biodiversity Commons, Ecology and Evolutionary Biology Commons, Other Animal Sciences Commons, Parasitology Commons, Veterinary Infectious Diseases Commons, Veterinary Pathology and Pathobiology Commons, and the Zoology Commons

Gettinger, Donald D., "Checklist of Bloodfeeding Mites (Acari: Spinturnicidae) from the Wings of Bats (Mammalia: Chiroptera) in the Manú Biosphere Reserve, Peru" (2018). MANTER: Journal of Parasite Biodiversity. 10.

https://digitalcommons.unl.edu/manter/10

This Article is brought to you for free and open access by the Parasitology, Harold W. Manter Laboratory of at DigitalCommons@University of Nebraska - Lincoln. It has been accepted for inclusion in MANTER: Journal of Parasite Biodiversity by an authorized administrator of DigitalCommons@University of Nebraska - Lincoln. 


\title{
Checklist of Bloodfeeding Mites (Acari: Spinturnicidae) from the Wings of Bats (Mammalia: Chiroptera) in the Manú Biosphere Reserve, Peru
}

\section{Donald Gettinger}

Harold W. Manter Laboratory of Parasitology, University of Nebraska State Museum, University of NebraskaLincoln, Lincoln, Nebraska, USA (donaldgettinger@gmail.com)

\begin{abstract}
A survey collection of mites of the family Spinturnicidae from Peruvian bats includes 11 species of Periglischrus (acutisternus, gameroi, grandisoma, herrerai, hopkinsi, iheringi, micronycteridis, ojasti, paracutisternus, paravargasi, and ramirezi) and 2 Spinturnix (americanus and bakeri); almost all represent new locality records. This survey collection is available for further study at the following repositories: The Harold W. Manter Laboratory of Parasitology, University of Nebraska-Lincoln; the Field Museum of Natural History, Chicago; and the Laboratório de Espeleobiologia y Acarologia, Universidad Nacional Autónoma de México. When spinturnicid mites are collected to avoid cross-contamination by mites among species of bats, parasitic associations are consistently host specific, with Periglischrus spp. distributed exclusively on phyllostomid bats, and Spinturnix spp. on vespertilionids. Notable disjunctions within the Manú Reserve include an absence of spinturnicids on bats of the genus Carollia (Phyllostomidae), or with Chiroderma villosum (Stenodermatinae). Mites of the family Spinturnicidae are not normally associated with bats of the families Emballonuridae, Molossidae, or Noctilionidae.
\end{abstract}

Keywords: bats, ectoparasites, Acari, Spinturnicidae, Periglischrus, Spinturnix

\section{Resumen}

En una colección de ácaros de la familia Spinturnicidae en murciélagos peruanos se encontraron 11 especies de Periglischrus (acutisternus, gameroi, grandisoma, herrerai, hopkinsi, iheringi, micronycteridis, ojasti, paracutisternus, paravargasi, y ramirezi) y 2 Spinturnix (americanus y bakeri); la mayoría representan nuevos registros de localidad. Esta colección está disponible para su posterior estudio en las siguientes instituciones: Laboratorio de Parasitología Harold W. Manter, Universidad de Nebraska-Lincoln, Field Museum of Natural History, Chicago, y Laboratorio de Espeleobiología y Acarología, Universidad Nacional Autónoma de México. Si los espinturnicidos se recolectan evitando la contaminación cruzada de los ácaros, entre las especies de murciélagos, las asociaciones parasitarias son consistentemente específicas al hospedador, con Periglischrus spp. distribuido exclusivamente en murciélagos phyllostomidos y Spinturnix spp. en vespertilionidos. Las disyunciones notables dentro de la Reserva de Manu incluyen una ausencia de espinturnicidos en los murciélagos del género Carollia (Phyllostomidae), o con Chiroderma villosum (Stenodermatinae). Los ácaros de la familia Spinturnicidae normalmente no están asociados con murciélagos de las familias Emballonuridae, Molossidae, y Noctilionidae.

\section{Introduction}

From 1999 through 2001, an elevational survey of bats and their associated ectoparasites was carried out within the
Manú Biosphere Reserve, a UNESCO World Heritage Site in Peru. This large protected area on the eastern slopes of the Andes is located (ca. $11^{\circ} 17^{\prime}-1311^{\prime} \mathrm{S}, 71^{\circ} 10^{\prime}-72^{\circ} 22^{\prime} \mathrm{W}$ ) in a region considered to be one of the most biodiverse 
in the world. The survey effort was led by a team of field biologists organized by the Field Museum of Natural History, Chicago (FMNH). Bats and their ectoparasitic arthropods were obtained from specific sites along an altitudinal transect ranging from the lowland forests on the bank of the Río Alto Madre de Dios to high on the eastern slopes of the Andes. Bats were collected at the following localities: Madre de Dios, Quebrada Aguas Calientes (450 m); Madre de Dios, Maskoitania (480 m); Cuzco, Consuelo (1000 m); Cuzco, San Pedro (1480 m); Cuzco, Suecia (1920 m); Cuzco, Pillahuata (2460 m); Cuzco, La Esperanza (2880 m); and Cuzco, Puesto de Vigilancia Acjanaco $(3450 \mathrm{~m})$. Bats were captured, primarily in mist nets, and taken to a temporary field laboratory, where they were individually euthanized, examined, and sampled for ectoparasites. Arthropods were preserved in carefully labeled vials of ethyl alcohol, linking each sample to a museum voucher specimen of the host individual. This survey was planned and organized with an emphasis on careful collecting of both bats and ectoparasites, hoping to limit data errors and problems caused by the contamination of one sample with the ectoparasites of another. All collected bats were accessioned into the Mammal Collection of the $\mathrm{FMNH}$; host identifications in this paper can be verified and updated online by searching the FMNH catalog numbers. More information on the Manú Biosphere Reserve, the surveys, and fauna may be found in Solari et al. (2006) and Patterson et al. (2006.)

Mites of the family Spinturnicidae (Acari: Mesostigmata) are permanent hematophagous parasites that occur on the wings and tail membranes of certain taxonomic groups of bats (Mammalia: Chiroptera). In the Neotropics, species of four genera of these ectoparasites are distributed exclusively across four families of bats. Species of the genus Spinturnix von Heyden 1826 are associated with Vespertilionidae, while species allocated to the genus Periglischrus Oudemans 1902 occur only on the Phyllostomidae. Species of Cameronieta Machado-Allison 1965 occur on the Mormoopidae, and species of Mesoperiglischrus Dusbábek 1968 occur only on bats of the family Natalidae. Species of Spinturnix are cosmopolitan in association with their widely distributed vespertilionid hosts, but the other three mite genera are primarily Neotropical in distribution. Species diversity of bats in the Manú Reserve is high, and representative species of seven families collected during the survey include the Emballonuridae, Phyllostomidae, Noctilionidae, Furipteridae, Thyropteridae, Molossidae, and Vespertilionidae. Of particular note, mites of the family Spinturnicidae were found only on species of Phyllostomidae (Periglischrus) and Vespertilionidae (Spinturnix). Despite efforts to collect representative species of all chiropterans in each geographical area investigated, bats of the families Mor- moopidae and Natalidae were not sampled in the Manú Reserve. Fifty-four species of phyllostomid bats were sampled for ectoparasites in this survey, and 40 species were found to be infested with spinturnicids (see Table 1). Taxonomically, all these mites were allocated to the 14 nominal species of Periglischrus.

This taxonomic species catalog presents the results of a field survey with subsequent identification of all spinturnicid mites recovered. This catalog also provides taxonomic information about the mites that were collected and prepared for identification and specific museum collections where specimens are deposited. Because the formal identification of representative specimens mounted on slides served as the basis for the determination of the remaining material that is preserved in vials of alcohol, this collection represents a source of comparative material for further research on spinturnicid mites in the Neotropical region. The synoptic collection of specimens mounted on microscope slides that were identified includes catalog numbers HWML139513-139821. The Manú survey research collection of voucher specimens in alcohol was deposited in the arthropod collections of the FMNH; another smaller collection of spinturnicid material from this survey was deposited at the Laboratorio de Espeleobiologia y Acarologia, Universidad Nacional Autónoma de Mexico (UNAM).

\section{Species Accounts}

Each species account includes the following sections:

(1) Type Host and Locality: Taken from the original species description.

(2) Remarks: Parasite-host relationships observed in the Manú Reserve are compared with those reported in the literature. Definitions used in the Remarks sections include:

Monoxenous associations include permanent relationships with a single host species.

Stenoxenous associations include associations of mites with a monophyletic group that usually includes a single genus (or subgenus) of host.

Oligoxenous associations include associations of mites with a relatively wide range of phylogenetically related hosts.

Polyxenous associations include mites that occur on bats that have separate phylogenetic histories and are not monophyletic (no polyxenous spinturnicids are known).

(3) Reference(s): Includes other records of this host/ mite association published since the seminal work of Rudnick (1960). 
No. 10. Gettinger, Bloodfeeding Mites ... of Bats ... in Manú Biosphere Reserve, Peru

Acari: Mesostigmata: Spinturnicidae

Periglischrus Kolenati, 1857

Type of the Genus: Periglischrus caligus Kolenati, 1857, by subsequent designation (Oudemans, 1903).

Remarks: Periglischrus caligus is a stenoxenous associate of glossophagine bats of the genus Glossophaga. Although these bats were not recovered during the Manú survey, Mendoza-Uribe and Chavez-Chorocco (2002) previously reported this mite from Glossophaga soricina (Pallas, 1766) from the District of Los Aquijes, Peru.

\section{Periglischrus acutisternus Machado-Allison, 1964}

Type Host and Locality. Phyllostomus elongatus (É. Geoffroy, 1810), Cariptio, Monagas State, Venezuela.

Remarks: Stenoxenous, associated with bats of the genus Phyllostomus in the Manú Reserve. This large-bodied species of mite often occurs in a presumed sympatric relationship with the smaller-bodied $P$. torrealbai; both species were collected from 4 of 7 spinturnicid-infested $P$. hastatus and from 1 of $2 P$. elongatus.

References: Venezuela: Machado-Allison, 1964; MachadoAllison, 1965; Herrin and Tipton, 1975. BRAZIL: Confalonieri, 1976; Gettinger and Gribel, 1989; Dantas-Torres et al., 2009; Silva and Graciolli, 2013. ColombiA: Marinkelle and Grose, 1981. Costa Rica: Casebeer, 1966. Panama: Furman, 1966.

\section{Periglischrus gameroi Machado-Allison and Antequera, 1971}

Type Host and Locality: Lonchorhina aurita Tomes, 1863, 18 km N Valera (El Cenizo), Trujillo State, Venezuela.

Remarks: Stenoxenous on Lonchorhina spp. This species is known from both $L$. aurita and L. orinocensis in Venezuela (Herrin and Tipton, 1975). This is a new record of this association with the type host in the Manú Reserve.

References: VenezUeLA: Machado-Allison and Antequera, 1971; Herrin and Tipton, 1975.

\section{Periglischrus grandisoma Herrin and Tipton, 1975}

Type Host and Locality: Phylloderma stenops Peters, 1865, San Juan Rio Manipare, 163 km ESE of Puerto Ayacucho, Territorio Federal Amazonas, Venezuela.

Remarks: Monoxenous. This is a large-bodied species of wing mite that infests the monotypic type host, $P$. stenops. Periglischrus grandisoma occurs in association with the smaller P. paratorrealbai, often occurring on the same host individuals. These associations are known among species of Phylloderma and Phyllostomus, but it is possible that these sympatric pairs occur in other species of the Phyllostominae. Confalonieri (1976) reported on a series of spinturni-
cids-3F, 2M, 6DN, 1PN from P. stenops in Brazil-but failed to identify the specimens to the level of the species. These specimens may actually be referable to the sympatric pair $P$. grandisoma/P. paratorrealbai, but these mites need to be examined and identified.

Reference: Venezuela: Herrin and Tipton, 1975.

\section{Periglischrus herrerai Machado-Allison, 1965}

Type Host and Locality: Desmodus rotundus rotundus (É. Geoffroy, 1810), from Caripito, Monagas, Venezuela.

Remarks: Monoxenous, known only from the common vampire, $D$. rotundus. Spinturnicids are as yet unknown from the other desmodontines, including Diphylla ecaudata Spix, 1823 and Diaemus youngi (Jentink, 1893).

References: Venezuela: Machado-Allison, 1965; Herrin and Tipton, 1975. Brazil: Confalonieri, 1976; Gettinger and Gribel, 1989; Almeida et al., 2011; Silva and Graciolli, 2013. ColombiA: Machado-Allison and Antequera, 1969; Marinkelle and Grose, 1981; Tarquino-Carbonel et al., 2015. Mexico: Sheeler-Gordon and Owen, 1999. Panama: Furman, 1966; Morales-Malacara et al., 2017. Paraguay: MoralesMalacara et al., 2017. Peru: Mendoza-Uribe and ChavezChorocco, 2002. TRINIDAD: Furman, 1966.

\section{Periglischrus hopkinsi Machado-Allison, 1965}

Type Host and Locality: Lionycteris spurrelli Thomas, 1913 from the Boca de Villacoa (río Orinoco), Bolívar, Venezuela.

Remarks: A single male of $P$. hopkinsi was collected from the L. spurrelli in the Manú Reserve. Periglischrus hopkinsi is known only from females; males remain undescribed. I am not formally describing this specimen at this time. Although this species was described using females from L. spurrelli, Herrin and Tipton (1975) reported it also from species of Lonchophylla. More collections are needed from lonchophylline bats.

Reference: Herrin and Tipton (1975).

\section{Periglischrus iheringi Oudemans, 1902}

Type Host and Locality: Platyrrhinus lineatus (É. Geoffroy, 1810), Sao Paulo, Brazil.

Remarks: Periglischrus iheringi is oligoxenous and the most commonly collected wing mite in the Neotropics. This name is applied to mites infesting the wings of stenodermatine bats, the most speciose subfamily of the Phyllostomidae. In the Manú Reserve, nineteen species belonging to eight genera of stenodermatines were infected with this highly composite mite species.

References: PeRu: Mendoza-Uribe and Chavez-Chorocco, 2002. Mexico: Sheeler-Gordon and Owen, 1999. ColomBIA: Marinkelle and Grose, 1981. Costa RicA: Casebeer, 1966. Panama: Furman, 1966. CubA: Silva Taboada, 1965; 
Dusbábek, 1968. BrazIL: Confalonieri 1976; Gettinger and Gribel, 1989; Azevedo et al., 2002; Lima-Silva et al., 2009; Dantas-Torres et al., 2009; Silva and Graciolli, 2013; Almeida et al., 2011; Almeida et al., 2016.

\section{Periglischrus micronycteridis Furman, 1966}

Type Host and Locality: Micronycteris megalotis (Gray, 1842) from near Borinquen Highway (Canal Zone), Panama.

Remarks: Stenoxenous; on certain phyllostomine Micronycteris Gray, 1866. In the Manú Reserve, we collected $P$. micronycteridis from both Micronycteris minuta (Gervais, 1856) and M. megalotis.

References: Panama: Furman, 1966. Venezuela: Herrin and Tipton, 1975.

\section{Periglischus ojasti Machado-Allison, 1964}

Type Host and locality: Sturnira lilium (É. Geoffroy, 1810) from Caripito, Monagas, Venezuela.

Remarks: Periglischus ojasti is stenoxenous, associated with bats of the genus Sturnira Gray, 1842, infesting $S$. erythromos (Tschudi, 1844); S. lilium; S. magna de la Torre, 1966; S. ororaphilum (Tschudi, 1844); and S. tildae de la Torre, 1959 in the Manú Reserve.

References: Venezuela: Machado-Allison, 1964; MachadoAllison, 1965; Herrin and Tipton, 1975. CostA RICA: Casebeer, 1966. PANAMA: Furman, 1966 (as P. aitkeni syn.). DominiCA: Pence et al., 1981. Colombia: Marinkelle and Grose, 1981. BrAZIL: Confalonieri, 1976; Gettinger and Gribel, 1989; Azevedo et al., 2002; Lima-Silva and Graciolli, 2013; Almeida et al., 2016. Mexıco: Sheeler-Gordon and Owen, 1999.

\section{Periglischrus paracutisternus Machado-Allison and Antequera, 1971}

Type Host and Locality: Trachops cirrhosus (Spix, 1823), 19 km NW Urama, Yaracuy State, Venezuela.

Remarks: Monoxenous. Periglischrus paracutisternus was collected exclusively from the monotypic T. cirrhosus in the Manú Biosphere Reserve, Peru.

References: Venezuela: Machado-Allison and Antequera, 1971; Herrin and Tipton, 1975. BRAZIL: Almeida et al., 2016.

\section{Periglischrus paravargasi Herrin and Tipton 1975}

Type Host and Locality: Anoura caudifer (É. Geoffroy, 1818) from 2 km SW Altamira, Barinas, Venezuela.

Remarks: Gettinger and Gribel (1989) found high prevalence of $P$. paravargasi infesting $A$. caudifer in the cerrados of central Brazil. However, this mite was encountered in low prevalence from Anoura caudifer in the Manú Biosphere Reserve, Peru.

References: Venezuela: Herrin and Tipton, 1975. BraziL: Confalonieri, 1976; Gettinger and Gribel, 1989.

\section{Periglischrus ramirezi Machado-Allison and Antequera, 1971}

Type Host and Locality: Rhinophylla pumilio Peters, 1865, 59 km SE El Dorado (El Mónaco), Bolívar State, Venezuela.

Remarks: Monoxenous. Except for a single record from Rhinophylla pumilio in Pará, P. ramirezi has been reported only from Venezuela (Machado-Allison and Antequera, 1971; Herrin and Tipton, 1975). Periglischrus ramirezi was collected exclusively from $R$. pumilio in the Manú Biosphere Reserve, Peru.

References: Machado-Allison and Antequera, 1971; Herrin and Tipton, 1975.

\section{Periglischrus tonatii Herrin and Tipton, 1975}

Type Host and Locality: Holotype female ex. Lophostoma silvicolum d'Orbigny, 1836, from 25 km S Puerto Ayacucho, Territorio Federal Amazonas, Venezuela; allotype male from L. carrikeri (J. A. Allen, 1910), San Juan, Rio Manapiare (155 m), 163 km ESE Puerto Ayacucho, Territorio Federal Amazonas, Venezuela.

Remarks: This species appears to be stenoxenous, occurring only on Lophostoma spp. Samples of $P$. tonatii were collected in the Manú Reserve from the same species as the original type hosts in Venezuela, Lophostoma silvicola and L. carrikeri.

References: Venezuela: Herrin and Tipton, 1975. Brazil: Silva and Graciolli, 2013.

\section{Periglischrus torrealbai Machado-Allison, 1965}

Type Host and Locality: Phyllostomus hastatus (Pallas, 1767), Valle de Caripe, Estado Monagas, Venezuela.

Remarks: Periglischrus torrealbai is the smaller of the two congeneric species occurring in sympatry on bats of the genus Phyllostomus Lacépède, 1799. Of seven spinturnicidinfested $P$. hastatus, six were infested with torrealbai, four in sympatry with acutisternus. Of two infested $P$. elongatus (É. Geoffroy, 1810), both were infested with torrealbai, one in sympatry with acutisternus. Almeida et al. (2017) have shown that populations of $P$. torrealbai, occurring on different though closely related phyllostomine hosts, display clear and concordant morphometric differences. More field studies are needed to discover how widely these sympatric species-pairs are distributed within the host subfamily Phyllostominae.

References: Venezuela: Machado-Allison, 1964; Machado-Allison, 1965; Herrin and Tipton, 1975. CostA RICA: Casebeer, 1966. PANAMA: Furman, 1966 (as P. inflatiseta syn.). BRAZIL: Confalonieri, 1976; Gettinger and Gribel, 1989; Almeida et al., 2011; Silva and Graciolli, 2013; Almeida et al., 2016. 


\section{Periglischrus vargasi Hoffmann, 1944}

Type Host and Locality: Leptonycteris nivalis (Saussure, 1860), Yerbabuena, Estado Guerrero, Mexico.

Remarks: Periglischrus vargasi is a monoxenous parasite of Anoura geoffroyi Gray, 1838, in the Manú Preserve. The species boundaries of the "vargasi species group" are distributed broadly across the glossophagine genera Anoura Gray, 1838 and Leptonycteris Lydekker, 1891.

References: MeXICO: Hoffman, 1944; Sheeler-Gordon and Owen, 1999. CuBA: Dusbábek, 1968. VenezuelA: MachadoAllison, 1965 (as P. squamosus syn.). BrAzIL: Silva et al., 2009; Almeida et al., 2016.

\section{Spinturnix von Heyden, 1826}

Type of the Genus: Pteropus myoti Kolenati, 1856, designated by Opinion 128 of the International Commission on Zoological Nomenclature (1936). [= Spinturnix myoti (von Heyden, 1826)]

Remarks: The taxonomic boundaries among species of Spinturnix remain poorly defined in the New World, and even host associations are unclear.

\section{Spinturnix americanus (Banks, 1902)}

Type Host and Locality: Originally reported as a "bat" from a cave in Indiana. Rudnick (1960) proposed Myotis lucifugus lucifugus (LeConte, 1831) as the type host.

Remarks: Spinturnicids were not abundant in collections from vespertilionids, but the series of slides from Myotis albescens (É. Geoffroy, 1806) FMNH170275 is excellent, with all the life stages present. Spinturnix americanus appears to be a stenoxenous parasite of certain species of Myotis, throughout the New World.

References: BRAZIL: Silva and Graciolli, 2013. DoMINICA: Pence et al., 1981. Venezuela: Herrin and Tipton, 1975.

\section{Spinturnix bakeri Rudnick, 1960}

Type Host and Locality: Eptesicus fuscus bernardinus Rhodes from Sunol, Alameda County, California.

Remarks: These mites fall into Rudnick's "group 3," with long lateroventral leg setae, and one of two proximal dorsal setae of femurs I and II are minute. This species infects the common bat, Eptesicus fuscus (Palisot de Beauvois, 1796), distributed throughout the Nearctic and into the northern Neotropical region. In Venezuela, Herrin and Tipton (1975) reported this mite from Eptesicus montosus (=E. andinus Allen, 1914).

References: CuBA: Dusbábek, 1968. VenezUelA: Herrin and Tipton, 1975.

\section{Discussion}

Even with relatively recent advances in our understanding of spinturnicid morphology (Morales-Malacara, 2001), the conservative taxonomy of the Neotropical Spinturnicidae is probably inadequate for species-level identifications. If so, this catalog may greatly underestimate the number of Periglischrus spp. infesting bats from Manú. High levels of intraspecific variation in morphology, especially of the female stase, continue to confound species boundaries within the genus Periglischrus. This extreme heteromorphy may be due to the effects of neosomy and accumulating wear and tear on the exoskeleton (teratologies) during a long reproductive lifespan on the exposed wing membranes of a proportionately long-lived host. However, even with these morphometric problems, the taxonomic foundations of the genus reveal clear morphological groupings (Morales-Malacara 2001), and the dichotomous key presented by Herrin and Tipton (1975) remains useful in identifying the adult stase of Neotropical spinturnicids and assigning consistent taxonomic names to the mites with stenoxenous and oligoxenous host associations.

Although biological observations on the Neotropical Spinturnicidae are lacking in the literature, some general aspects of the structure of spinturnicid populations are revealed by examining the basic collection data from the Manú Reserve. Spinturnicid mite populations tend to be highly biased toward the adult stase. Of a total of 1,287 individual mites collected from the wings of 1,051 bats, $51 \%$ were females, $30 \%$ males, $11 \%$ deutonymphs, and $8 \%$ protonymphs. Eighty-one percent of all the mites collected were adults, females and males in approximately even numbers, and $27 \%$ of the mature females were carrying an internal protonymph. Although slides of more than 200 reproductive females were examined, an internal larva was never observed. This developmental stage is either absent in Periglischrus or very short in duration.

The lineage specificity of Neotropical Spinturnicidae is clear; no mites of the family were observed nor collected from any nonchiropteran vertebrates; in addition, despite intense collection efforts, no mites of this family were collected from bats of the families Emballonuridae $(n=9)$, Noctilionidae $(n=10)$, Thyroptidae $(n=1)$, or Molossidae $(n=7)$. Relatively few bats of the family Vespertilionidae $(n=43)$ were sampled, and the infestation rates with Spinturnix spp. were low when compared to those of the Phyllostomidae. Within the phyllostomid subfamily Carollinae, although $P$. ramirezi is a monoxenous parasite of Rhinophylla pumilio, bats of the genus Carollia are uninfested with spinturnicid mites. Herrin and Tipton (1975) encountered the same relationships with the large and extensive 
Smithsonian Venezuela Collection. Rhinophylla pumilio was strongly infected with P. ramirezi, but 6665 host samples from Carollia spp. contained only 24 spinturnicids; a prevalence of $0.0036(0.36 \%)$. These rare associations are very likely caused by sampling error; spinturnicid mites do not naturally infest bats of the genus Carollia. In the Manú Reserve, another interesting disjunction in the distribution of Periglischrus was observed (see Table 1); the lack of Periglischrus iheringi in association with the stenodermatine, Chiroderma villosum $(n=33)$. In Venezuela, Herrin and Tipton also report this negative association, with a much larger sample size; two mites collected from a host sample of 724 C. villosum. Based on some experience in the field, I have also never observed spinturnicid mites on Chrotopterus aurita nor on the desmodontines, Diaemus and Diphylla. More survey research is needed, employing rigorous sampling protocols, and with careful collection and identification of both parasite and host voucher specimens.

Acknowledgments - This paper is based on collections made by personnel of the Field Museum of Natural History, Chicago, and was supported by the NSF (DEB-9870191 to B. D. Patterson, D. F. Stotts, and J. W. O. Ballard), the Field Museum (especially the Marshall Field III Fund, the Barbara E. Brown Fund for Mammal Research, and a gift from Jake and Catherine Jacobus), and the Museo de Historia Natural, Universidade de San Marcos, Lima, Peru.

\section{Literature Cited}

Almeida, J. C.; Costa Gomes, L. A; and Owen, R. D. 2017. Morphometric variation in Periglischrus torrealbai (Acari: Spinturnicidae) on three species of host bats (Chiroptera: Phyllostomidae) with a new record of host species. Parasitology Research 117: 257-264.

Almeida, J. C.; Gettinger, D.; and Gardner, S. L. 2016. Taxonomic review of the wingmite genus Cameronieta (Acarina: Spinturnicidae) on Neotropical bats, with a new species from northeastern Brazil. Comparative Parasitology 83: 212-220.

Almeida, J. C.; Silva, S. P. P.; Serra-Freire, N. M.; and Valim, M. P. 2011. Ectoparasites (Insecta and Acari) associated with bats in southeastern Brazil. Journal of Medical Entomology 48: 753-757.

Azevedo, A. A.; Linardi, P. M.; and Coutinho, M. T. Z. 2002. Acari ectoparasites of bats from Minas Gerais, Brazil. Journal of Medical Entomology 39: 553-555.

Casebeer, R. S. 1966. Systematics and host relationships of the mites of the family Spinturnicidae in Costa Rica. PhD diss., University of Southern California.

Colín-Martinez, H.; and García-Estrada, C. 2016. Richness, infestation and specificity of spinturnicid mites (Acari: Spinturnicidae) on bats in southern Oaxaca, Mexico. Experimental and Applied Acarology 70: 155-164.
Colín-Martínez, H.; Morales-Malacara, J. B.; and García-Estrada C. 2018. Epizoic fauna survey on phyllostomid bats (Chiroptera: Phyllostomidae) in a shaded coffee plantation of southeastern Chiapas, Mexico. Journal of Medical Entomology 55: 172-182.

Confalonieri, U. E. C. 1976. Sobre a família Spinturnici dae Oudemans, 1902 e seus hospedeiros no Brasil, com um estudo biometrico de Periglischrus iheringi Oudemans, 1902, e Periglischrus ojastii Machado-Allison, 1964. Tese, Universidade Federal Rural do Rio de Janeiro.

Dantas-Torres, F.; Soares, F. A. M.; Ribeiro, C. E. B. P.; Daher, M. R. M.; Valença, G. C.; and Valim, M. P. 2009. Mites (Mesostigmata: Spinturnicidae and Spelaeorhynchidae) associated with bats in northeast Brazil. Journal of Medical Entomology 46: 712-715.

Dusbábek, F. 1968. Los acaros Cubanos de la familia Spinturnicidae (Acarina), con notas sobre su especificidad de hospederos. Poeyana Instituto De Biologia (La Habana) Ser. A, 57: 1-31.

Dusbábek, F.; and Lukoschus, F. 1971. Some Spinturnicidae (Acarina: Mesostigmata) from Surinam bats. Parasitic mites of Surinam IX. Folia Parasitologica (Praha) 18: 149-154.

Furman, D. P. 1966. The spinturnicid mites of Panama. In Ectoparasites of Panama, R. L. Wenzel and V. J. Tipton (eds.). Field Museum of Natural History, Chicago. 125-166 p.

Gettinger, D.; and Gribel, R. 1989. Spinturnicid mites (Gamasida: Spinturnicidae) associated with bats in central Brazil. Journal of Medical Entomology 26: 491-493.

Herrin, C. S.; and Tipton, V. J. 1975. Spinturnicid mites of Venezuela (Acarina: Spinturnicidae). Brigham Young University Science Bulletin, Biological Series, vol. 20, no. 2 (1): 1-72.

Hoffmann, A. 1944. Periglischrus vargasi n. sp. (Acarina: Parasitidae). Revista del Instituto de Salubridad y Enfermidades Tropicales, 5: 91-96.

Lima Silva, C.; and Graciolli, G. 2013. Prevalence, mean intensity of infestation and host specificity of Spinturnicidae mites (Acari: Mesostigmata) on bats (Mammalia: Chiroptera) in the Pantantal, Brazil. Acta Parasitologica 58: 174-179.

Lima Silva, C.; Graciolli, G.; and Rui, A. M. 2009. Novos registros de ácaros ectoparasitos (Acari, Spinturnicidae) de morcegos (Chiroptera, Phyllostomidae) no Rio Grande do Sul, Brasil. Chiroptera Neotropical 15: 469-471.

Machado-Allison, C. E. 1964. Notas sobre Mesostigmata neotopicales. II. Cuatro nuevas especies de Periglischrus Kolenati, 1957 (Acarina: Spinturnicidae). Revista Sociedad Mexicana de Historia Natural 25: 193-207.

Machado-Allison, C. E. 1965. Las especies Venezolanas del genero Periglischrus Kolenati 1857 (Acarina, Mesostigmata, Spinturnicidae). Acta Biologica Venezuelica, Universidade Central de Venezuela, Caracas. 259-301 p.

Machado-Allison, C. E.; and Antequera, R. 1971. Notes on Neotropical Mesostigmata VI: Four new Venezuelan species of the genus Perglischrus (Acarina: Spinturnicidae). Smithsonian Contributions to Zoology 93: 1-16.

Marinkelle, C. J.; and Grose, E. S. 1981. A list of ectoparasites 
of Colombian bats. Revista de Biología Tropical (n.s.) 29: 11-20.

Mendoza-Uribe, L., and Chavez-Chorocco, J. 2002. New records of mites (Gamasida: Spinturnicidae) on Peruvian bats (Quiroptera: Phyllostomidae). Revista de Biología Tropical 51: 276-277.

Morales-Malacara, J. B. 2001. New morphological analysis of the bat wing mites of the genus Periglischrus (Acari: Spinturnicidae). Acarology: Proceedings of the 10th International Congress. R. B. Halliday, D. E. Walter, H. C. Proctor, R. A. Norton, and M. J. Colloff (eds.). CSIRO Publishing, Melbourne.

Morales-Malacara, J. B. 2002. Variacion interespecifica en poblaciones de acaros parasitos del genero Periglischrus (Mesostigmata: Spinturnicidae) asociados a murcielagos del genero Leptonycteris (Chiroptera: Phyllostomidae). Entomologia Mexicana 1: 56-59.

Morales-Malacara, J. B.; Aldana, L. Y. M.; Reyes-Novelo, E.; Almazán-Marín, C. E.; Ruiz-Pina, H. A.; Cuxim-Koyoc, A.; Aguilar-Setién, A.; Colín-Martinez, H.; Garcia-Estrada, C.; and Ojeda, M. 2018. Redescription of Periglischrus herrerai (Acari: Spinturnicidae) associated to Desmodus rotundus (Chiroptera: Phyllostomidae: Desmodontinae), with a description of adult female heteromorphism and an analysis of its variability throughout the neotropics. Journal of Medical Entomology 55: 300-316.

Morales-Malacara, J. B., and Juste, J. 2002. Two new species of the genus Periglischrus (Acari: Mesostigmata: Spinturnicidae) on two bat species of the genus Tonatia (Chiroptera: Phyllostomidae) from southeastern Mexico, with additional data from Panama. Journal of Medical Entomology 39: 298-311.

Patterson, B. D.; Stotz, D. F.; and Solari, S. 2006. Biological surveys and inventories in Manu. In Mammals and Birds of the Manu Biosphere Reserve, Peru, B. D. Patterson, D. F. Stotz, and S. Solari (eds.). Fieldiana: Zoology, n.S., No. 110. 3-12 p.
Pence, D. B.; Jones, J. K.; and Knipping, P. A. 1981. Acari of Antillean Bats (Chiroptera). Journal of Medical Entomology 18 (4): 353-354.

Presley, S. J. 2004. Ectoparasitic assemblages of Paraguayan bats: Ecological and evolutionary perspectives. PhD diss., Texas Tech University, Lubbock.

Rudnick, A. 1960. A revision of the mites of the family Spinturnicidae. University of California Publications in Entomology 17: 157-283.

Sheeler-Gordon, L. L.; and Owen, R. D. 1999. Host tracking or resource tracking? The case of Periglischrus wing mites (Acarina: Spinturnicidae) of leaf-nosed bats (Chiroptera: Phyllostomidae) from Michoacan, Mexico. Acta Zoologica Mexicana (n.s.) 76: 85-102.

Silva, C. L.; and Graciolli, G. 2013. Prevalence, mean intensity of infestation and host specificity of Spinturnicidae mites (Acari: Mesostigmata) on bats (Mammalia: Chiroptera) in the Pantanal, Brazil. Acta Parasitologica 58: 174-179.

Silva, C. L.; Graciolli, G.; and Rui, A. M. 2009. Novos registros de ácaros ectoparasitos (Acari, Spinturnicidae) de morcegos (Chiroptera, Phyllostomidae) no Rio Grande do Sul, Brasil. Chiroptera Neotropical 15: 469-471.

Silva Taboada, G. 1965. Lista de los parasitos hallados en murciélagos cubanos. Poeyana, La Habana, ser. A, 12: 1-14.

Solari, S.; Pacheco, V.; Luna, L.; Velazco, P. M.; and Patterson, B. D. 2006. Mammals of the Manú Biosphere Reserve. In Mammals and Birds of the Manú Biosphere Reserve, Peru, B. D. Patterson, D. F. Stotz, and S. Solari (eds.). Fieldiana: Zoology, n.s., No. 110. 13-23 p.

Tarquino-Carbonel, A. P.; Gutiérrez-Díaz, K. A.; Galindo-Espinosa, E. Y.; Reinoso-Flórez, G.; Solari, S.; and Guerrero, R. 2015. Ectoparasites associated with bats in northeastern Tolima, Colombia. Mastozoologia Neotropical 22: 349-358. 
Table 1. Chiroptera sampled for ectoparasites in the Manú Biosphere Reserve

\begin{tabular}{|c|c|c|c|c|}
\hline & \# Sampled & \# Infested & \# With spints & Prevalence \\
\hline \multicolumn{5}{|l|}{ Emballonuridae } \\
\hline Saccopteryx bilineata & 7 & 7 & $0^{*}$ & - \\
\hline Saccopteryx leptura & 1 & 0 & 0 * & - \\
\hline Peropteryx leucoptera & 1 & 0 & $0^{*}$ & 一 \\
\hline
\end{tabular}

\section{Noctilionidae}

Noctilio albiventris

\section{Phyllostomidae}

\section{Phyllostominae}

Chrotopterus auritus

Phyllostomus elongatus

Phyllostomus hastatus

Phylloderma stenops

Trachops cirrhosa

Lophostoma silvicola

Tonatia carrikeri

Lonchorhina aurita

Micronycteris hirsutus

Micronycteris megalotis

Micronycteris minuta

\section{Desmodontinae}

Desmodus rotundus

\section{Glossophaginae}

Anoura caudifer

Anoura cultrata

18

Anoura geoffroyi

Anoura sp.

Choeronyscus sp.

Lionycteris spurrelli

Lonchophylla handleyi

Lonchophylla thomasi
1

45

1

1

5

1

9

\section{Carollinae}

Rhinophylla pumilio

Carollia brevicauda

Carollia castanea

Carollia perspicillata

Carollia sp.
17

44

28

67

11

14
1
42
1
1
3
1
6

14

\section{Sturnirinae}

Sturnira erythromos $\quad 109$ 
No. 10. Gettinger, Bloodfeeding Mites ... of Bats ... in Manú Biosphere Reserve, Peru

Table 1. Chiroptera sampled for ectoparasites in the Manú Biosphere Reserve (continued)

\begin{tabular}{|c|c|c|c|c|}
\hline & \# Sampled & \# Infested & \# With spints & Prevalence \\
\hline \multicolumn{5}{|l|}{ Stenodermatinae } \\
\hline Chiroderma salvini & 15 & 15 & 4 & 0.27 \\
\hline Chiroderma trinitatum & 9 & 9 & 4 & 0.44 \\
\hline Chiroderma villosum & 33 & 20 & 0 * & 0.00 \\
\hline Vampressa bidens & 21 & 17 & 10 & 0.59 \\
\hline Vampressa brocki & 2 & 2 & 0 & 0.00 \\
\hline Vampressa melissa & 5 & 3 & 1 & 0.20 \\
\hline Vampressa pusilla & 2 & 1 & 1 & 1.00 \\
\hline Uroderma bilobatum & 32 & 21 & 9 & 0.28 \\
\hline Uroderma magnirostris & 6 & 3 & 0 & 0.00 \\
\hline Mesophylla macconnelli & 4 & 4 & 0 & 0.00 \\
\hline Vampyrodes caraccioli & 23 & 19 & 13 & 0.57 \\
\hline Platyrrhinus brachycephalus & 36 & 23 & 9 & 0.25 \\
\hline Platyrrhinus dorsalis & 14 & 10 & 8 & 0.57 \\
\hline Platyrrhinus helleri & 27 & 22 & 13 & 0.48 \\
\hline Platyrrhinus infuscus & 15 & 14 & 4 & 0.27 \\
\hline Platyrrhinus nigellus & 15 & 12 & 5 & 0.33 \\
\hline Platyrrhinus vittatus & 3 & 2 & 2 & 0.67 \\
\hline Enchisthenes hartii & 34 & 30 & 28 & 0.82 \\
\hline Dermanura anderseni & 18 & 11 & 5 & 0.28 \\
\hline Dermanura glauca & 42 & 31 & 18 & 0.43 \\
\hline Dermanura gnoma & 9 & 5 & 2 & 0.22 \\
\hline Artibeus lituratus & 35 & 31 & 18 & 0.51 \\
\hline Artibeus obscurus & 41 & 28 & 1 & 0.02 \\
\hline Artibeus planirostris & 37 & 33 & 21 & 0.57 \\
\hline
\end{tabular}

\section{Thyropteridae}

Thyroptera lavali

\section{Molossidae}

Tadarida brasiliensis

Molossus ater

\section{Vespertilionidae}

Eptesicus brasiliensis

Eptesicus chiriquinus

Myotis albescens

Myotis keaysi

Myotis nigricans

Myotis oxyotus

Myotis riparius

$4 \quad 4$

$3-3$

$\begin{array}{rrrr}7 & 7 & 2 & 0.29 \\ 6 & 6 & 3 & 0.50 \\ 10 & 9 & 8 & 0.80 \\ 5 & 5 & 1 & 0.20 \\ 7 & 5 & 0 & 0.00 \\ 1 & 1 & 0 & 0.00 \\ 7 & 7 & 0 & 0.00\end{array}$

* Negative associations previously reported in the literature 